\title{
Is the alpine divide becoming more permeable to biological invasions? - Insights on the invasion and establishment of the Walnut Husk Fly, Rhagoletis completa (Diptera: Tephritidae) in Switzerland
}

\author{
M. Aluja ${ }^{1 *}$, L. Guillén ${ }^{1}$, J. Rull ${ }^{1}$, H. Höhn ${ }^{2}$, J. Frey $^{2}$, \\ B. Graf ${ }^{2}$ and J. Samietz ${ }^{2}$ \\ ${ }^{1}$ Instituto de Ecología, A.C., Apartado Postal 63, 91000 Xalapa, Veracruz, \\ México: ${ }^{2}$ Swiss Federal Research Station Agroscope Changins-Wädenswil \\ ACW, Schloss, CH-8820 Wädenswil, Switzerland
}

\begin{abstract}
The Walnut Husk Fly, Rhagoletis completa Cresson (Diptera: Tephritidae), is native to North America (Midwestern US and north-eastern Mexico) and has invaded several European countries in the past decades by likely crossing the alpine divide separating most parts of Switzerland from Italy. Here, we determined its current distribution in Switzerland by sampling walnuts (Juglans regia L.) in ecologically and climatically distinct regions along potential invasion corridors. $R$. completa was found to be firmly established in most low altitude areas of Switzerland where walnuts thrive, but notably not a single parasitoid was recovered from any of the samples. Infested fruit was recovered in 42 of the 71 localities that were surveyed, with mean fruit infestation rate varying greatly among sites. The incidence of $R$. completa in Switzerland is closely related to meteorological mean spring temperature patterns influencing growing season length, but not to winter temperatures, reflecting survival potential during hibernation. Importantly, areas in which the fly is absent correspond with localities where the mean spring temperatures fall below $7^{\circ} \mathrm{C}$. Historical data records show that the natural cold barrier around the Alpine divide in the central Swiss Alps corresponding to such minimal temperatures has shrunk significantly from a width of more than $40 \mathrm{~km}$ before 1990 to around $20 \mathrm{~km}$ after 2000 . We hypothesize on possible invasion/expansion routes along alpine valleys, dwell on distribution patterns in relation to climate, and outline future research needs as the incursion of $R$. completa into Switzerland; and, more recently, other European countries, such as Germany, Austria, France and Slovenia, represent an example of alien species that settle first in the Mediterranean Basin and from there become invasive by crossing the Alps.
\end{abstract}

Keywords: Rhagoletis completa, Tephritidae, invasive alien species, invasion ecology, Switzerland

(Accepted 23 December 2010)

*Authors for correspondence

Fax: 522288421800 ext 4115

E-mail: martin.aluja@inecol.edu.mx 


\section{Introduction}

Alien insect species have become an increasing concern worldwide due to their significant ecological and economic impact (Mack et al., 2000; Mooney \& Hobbs, 2000; Pimentel et al., 2000; Clarke et al., 2005; Roll et al., 2007; Kenis et al., 2009). For example, in North America alone, invasive species (insects and other organisms) have been estimated to cause damage and losses of $c a$. US $\$ 137$ billion per year (Pimentel et al., 2000). According to Kenis et al. (2009), the majority of studies on the ecological effect of invasive insect species have been carried out in the past eight years, with two thirds of them occurring in North America and only about 5\% in Europe. Invasions of herbivorous arthropods in North America reflect historical patterns of movement, with the vast majority of introduced species in Canada being of Paleartic origin, particularly from Europe (Langor et al., 2009). Nevertheless, recent increases in trade with China have been accompanied by matching increases of invasive species of such origin (Langor et al., 2009). Based on the latter, it is expected that augmented trade from North America to Europe will also be accompanied by new biological invasions. Data by Kenis (2006) shows that in Switzerland there are over 300 established alien insect species, with numbers likely to increase as a result of recent liberalization of human movement within the Schengen Territory and expanding trade with commercial partners worldwide.

The speed at which invasions occur has been significantly increased in recent times as a result of mainly two factors: (i) expanding international trade and tourism (Mumford, 2002; Work et al., 2005; Westphal et al., 2008), and (ii) global warming (Dukes \& Mooney, 1999; Ricciardi, 2007). Global warming is also opening new pathways for alien organisms, as, for example, formerly impenetrable mountain passes gradually become milder, allowing the survival of adults that are wind carried (Chapman et al., 2004; Torrez-Diaz et al., 2007). Also, many invasive species, establishing transient populations that would normally vanish during cold winter months, now survive as a result of winter or, more importantly, spring months that are becoming milder (Cannon, 1998; Rosati \& Van Laerhoven, 2007).

Among the most worrisome groups of invasive insects, fruit flies (Diptera: Tephritidae) stand out, as their invasive capacity impacts society along several axes. (i) On an ecological level, invasive species, particularly highly polyphagous ones, can displace native species or compete for essential resources with them (Duyck et al., 2004). (ii) On an economic level, severe economic damage is inflicted as infested fruit and vegetables become unmarketable and inedible. In addition, the presence of invasive species severely restricts trade (Aluja \& Mangan, 2008). (iii) On a social level, invasive species such as the Medfly, Ceratitis capitata (Wiedemann) or Bactrocera invadens Drew, Tsuruta \& White can reap havoc, as wide-ranging eradication efforts can cause the appearance of secondary pests as natural enemy populations dwindle or entire local economies are sent into disarray because formerly stable trade commodities suddenly become scarce or cannot be exported anymore (Mumford, 2002; Drew et al., 2005).

Here, we dwell on the relatively recent invasion into Switzerland of a fruit fly belonging to the genus Rhagoletis Loew native to North America (R. completa Cresson), detailing its current distribution within the country, analyzing some biotic and abiotic factors that explain its establishment and rapid expansion and offering hypotheses as to possible invasion routes. Flies within the genus Rhagoletis are distributed in North and South America, all of Europe (Austria, Bulgaria, France, Germany, Greece, Italy, Netherlands, Norway, Poland, Portugal, Spain, Sweden, Switzerland, Turkey (EPPO/CABI, 1996)) and parts of Eurasia

In Switzerland, only Rhagoletis cerasi is endemic; but, in the past two to three decades, Rhagoletis completa and Rhagoletis cingulata (Loew) have invaded the country, most likely from Italy where the two species were first reported for Europe (Duso, 1991; Norrbom, 2004). R. completa was initially found near Venice and in the Friuli region (Duso, 1991), and its presence in Italy was shortly thereafter confirmed in Milano, Pavia, Novara, Varese and Sondrio (Ciampolini \& Trematerra, 1992). The first formal reports of the presence of $R$. completa and $R$. cingulata (originally reported as $R$. indifferens) in Switzerland originate from trap captures in the Ticino region (Merz, 1991; Mani et al., 1994; Lampe et al., 2005), indicating that these flies possibly invaded the country in the mid- to late 1980s. As is the case with other non-European species of Tephritidae, $R$. completa was regulated as a quarantine pest in Switzerland and presently still possesses this status (Swiss Federal Council, 2001). As noted above, R. indifferens Curran was also reported in Switzerland (Merz, 1991; Mani et al., 1994), but B. Merz later acknowledged that the specimens had been misidentified and were in fact $R$. cingulata (Merz \& Niehuis, 2001). So, there is no formal evidence that $R$. indifferens is or was ever present in Switzerland or anywhere else in Europe.

Rhagoletis completa belongs to the suavis species group where it has been placed together with $R$. boycei Cresson, $R$. suavis (Loew), R. juglandis Cresson, R. zoqui Bush and R. ramosae Hernández-Ortiz (Bush, 1966; Hernández-Ortíz, 1985; Smith \& Bush, 2000). It is native to Midwestern USA and north-eastern Mexico (Bush, 1966; Smith \& Bush, 2000; Chen et al., 2006) and was described from specimens collected in the USA in the late 1920s (Cresson, 1929). In the USA, it was originally restricted to the Midwestern part of the country, but between 1922 and 1925 it was reported in California (Boyce, 1934). On the west coast, the fly now ranges from southern California as far north as Washington State (Chen et al., 2006). In Mexico, it is restricted to the north east (Smith \& Bush, 2000) particularly the states of Coahuila, Nuevo León, and Tamaulipas (J. Rull, unpublished data). The known hosts of R. completa are Juglans nigra L., J. microcarpa Ber., J. californica S. Whatson, J. hirsuta Manning, J. hindsii, Jepson ex R.E. Smith, J. major (Torr.) A. Heller and J. regia L. (Bush, 1966; Smith \& Bush, 2000). In addition to infesting walnuts, R. completa has been reported infesting peaches, Prunus persica L. (Boyce, 1934), although this host affiliation is rare (Smith \& Bush, 2000). The few additional details on its biology can be summarized as follows: it goes through obligate diapause, is univoltine, is considered oligophagous, and is attacked by very few parasitoids (Boyce, 1934; Legner \& Goeden, 1987; Kasana \& AliNiazee, 1995, 1996; Ovruski et al., 2007). European populations in Italy exhibit one generation a year, with adult emergence spanning from early July to the second half of August. Oviposition occurs from late July to early September, with peaks between the 5th and 18th of August. First instar larvae have been recorded since early August, and mature larvae leave husks from late August onwards to pupate in the soil (Duso \& Dal Lago, 2006).

Economic damage is caused by $R$. completa larvae, especially when the infestation occurs in an early stage of walnut development from July until mid-August. Damage has 
been reported to occur on 74-91\% of fruit in untreated orchards, with fruit not developing fully and producing small nuts or on occasion shrivelled, mouldy kernels (Olhendorf, 2000; Duso \& Dal Lago, 2006). Furthermore, there is the suspicion that heavily infested fruit facilitates the penetration of pathogens into the edible nut, such as the fungus Marssonina juglandis (Lib.) Magnus and particularly the bacteria Xanthomonas campestris pv. juglandis (Pierce (Dye)), causing the actual nut (kernel) to shrink and lose weight and also to rot, producing considerable (sometimes total) yield loss as a consequence of mould growth and malformation of the kernel (Hislop \& Allen, 1983; Coates, 2005). Despite the fact that feeding activity of $R$. completa larvae in late infestations usually does not damage the commercially valuable kernel, it does interfere with the natural separation of the pulp from the nut shell, and this can render commercialization cumbersome or impractical. Black stains have to be removed from the nut skin with high water pressure or nuts must be bleached as consumers refuse or hesitate to buy stained nuts (Hislop \& Allen, 1983; Olhendorf, 2000).

Considering the fact that the history of $R$. completa in Europe and particularly Switzerland is fairly recent and that, since it was first reported in Italy by Duso (1991) and Ciampolini \& Trematerra (1992), its presence has been confirmed in other European countries such as Slovenia (Seljak, 1999), Austria (C. Lethmayer, personal communication), Germany (EPPO, 2004) and France (EPPO, 2008; Bouvet, 2009), we decided to investigate the current distribution of $R$. completa in Switzerland, as possibly global warming was generating suitable conditions for its expansion through the Alpine divide into formerly colder areas (Studer et al., 2005; IPCC, 2007).

A second goal of our survey was to try to gain insight into possible invasion/expansion routes into/within the country (and into neighbouring countries) and to identify potential sources of environmental resilience to the invasive alien. In the spirit of Primack et al. (2009), we were also interested in gaining insight into the ability of $R$. completa to persist in a new environment with changing climate.

\section{Materials and methods}

\section{Collection sites and climate parameters}

Samples were collected in a total of 71 sites scattered throughout Switzerland. A complete list of the localities is provided in Appendix 1, we first targeted valleys located along known paths of warm transalpine winds from the south (Föhn valleys). In particular we targeted two regions: (i) valleys in the cantons Grisons and Uri; and (ii) the flatlands of the entire canton Valais all the way from Brigg to Lake Geneva. Climatic regions, as a possible discriminating factor for incidence of $R$. completa and walnut infestation levels, were determined for individual sites on the basis of a simplified scheme following Müller (1980). We further discriminated among regions with distinct climatic conditions, such as the Jura Mountains, the midlands between Lake Geneva and Lake Constance, the north face of the Alps, the south face of the Alps beyond the Alpine divide and finally the Valais due to special conditions regarding adiabatic wind formation. Meteorological 30-year spring temperature means (March-May 1961-1990) were used as an integrating parameter reflecting growing season length and potential, respectively, and winter temperatures (December-February 1961-1990) were used as an integrating parameter reflecting winter length and potential for survival during hibernation. Such parameters were retrieved for all walnut collection sites from the software 'Atlas of Switzerland' Version 2.0 (Project KLIMA90: Aschwanden et al., 1996). Climatic parameters for each collection site are listed in Appendix 1.

For two possible south-north invasion pathways through the Gotthard region of the central Swiss Alps, yearly widths of the cold barrier unsuitable for establishment of $R$. completa around the Alpine divide were calculated from 1961 to 2010 on the basis of the homogeneous temperature series of Switzerland (Begert et al., 2005) applied to the digital climate map of spring temperatures implemented with the software 'Atlas of Switzerland' Version 2.0 (Aschwanden et al., 1996). Resolution of distance measurements was $1 \mathrm{~km}$.

\section{Fruit sampling and processing}

Most (>95\%) samples were gathered from tree canopies by direct harvest or with the aid of a $4 \mathrm{~m}$ telescopic scissor (expandable PVC tubing with a sharp curved scissor at end; Wallace, Enfield, CT, USA). Between 20 and 35 nuts were collected in every site (Appendix 2); but, if fruit were plentiful and heavily infested and we received explicit permission by the tree owners, up to 250 nuts were sampled. Fruit samples were placed in 10-1 transparent plastic bags that were labelled (date, name of collection site) and placed in plastic crates so as to allow us to maintain the upper end of the bag open to permit for aeration.

After collection, we weighed each bag the same day and then gently transferred fruit samples inside $33 \times 22 \times 9-\mathrm{cm}$ transparent Polystyrol containers, with a screened cover to allow for aeration (Lagerdosen PS glasklar, Semadeni AG, Ostermündingen, Switzerland). On the bottom of the container, we placed a layer of pure $0.1-0.6 \mathrm{~mm}$ quartz sand (minimum 93.3\% $\mathrm{SiO}_{2}$; Carlo Bernasconi AG, Bern, Switzerland) as a pupating medium. Since $R$. completa larvae wander before pupating and also creep along container walls/roof, we used three heavy duty rubber bands to guarantee that the container cover was tight, as otherwise many larvae would have escaped. In those cases where there was evidence of infestation by $R$. completa larvae, we took five such fruit from the sample for a single-fruit experiment, weighed them and placed them individually in 180-ml transparent Polystyrol cups (Joghurtbecher PS glasklar, Semadeni AG, Ostermündingen, Switzerland), into which we had also placed a layer of quartz sand in the bottom. The 180-ml cups were tightly covered with a plastic lid into which we had poked at least 100 holes with a needle to allow for aeration. Cups for the single-fruit experiment and containers with the remaining samples were then shifted to an exterior covered warehouse (i.e. ambient temperature) built with wire mesh to allow for ample aeration and protect samples from wild scavengers. Containers were randomly distributed on the warehouse subdivisions (bottom and top), avoiding stacking to allow for maximum aeration. Cups for the single-fruit experiment were placed in a plastic tray grouped by collection site.

\section{Processing of larvae, pupae and adults}

Approximately 45-60 days after fruit had been placed in the warehouse, we started to separate the pupae from the sand and debris. Fruit had totally disintegrated inside, but the 
hardened skin was mostly intact and had to be cracked open to search for dead larvae or pupae. To facilitate pupal recovery, we removed all fruit and then added water to the container so as to allow pupae/dead larvae to float. Prior to this, we had carefully inspected every fruit to remove any pupae or dead larvae that remained inside skin or nut crevices. Dead larvae were surprisingly well preserved and easily recognizable as their white body contrasted with the dark liquid of the decayed pulp. At this stage, we counted all nuts in the sample as fruit had not been individually counted when originally placed in the Polystyrol containers. This information was needed to calculate the number of larvae per fruit in the overall sample.

Both larvae and pupae were transferred into a colander, rinsed with tap water and placed in $90-\mathrm{mm}$ filter paper circles to let them dry. The next day at the latest, dead larvae and pupae were counted and viable pupae transferred into a 180-ml transparent Polystyrol cup with a layer of moistened quartz sand in the bottom. Some pupae were rotten or hollow and were discarded after they had been tallied so as to avoid fungal growth that could damage the healthy pupae. In the case of the single-fruit experiment, each individual pupa was weighed. After weighing, all pupae from a particular collection site that had been kept individually were placed together with those stemming from the larger sample (same location). From this pool, we separated 20 pupae (if so many were available), transferred them into 0.5-ml Eppendorf tubes and placed them at $-80^{\circ} \mathrm{C}$ in an ultra freezer for future genetic analysis.

After the separation, rinsing and counting procedure, all pupae were transferred into a climatic chamber kept at $13^{\circ} \mathrm{C}$ until early January, and then the temperature was raised to $27^{\circ} \mathrm{C}$ to artificially break the diapause. During the test, the pupae/sand were moistened regularly. All cups containing the pupae were then transferred to a room kept at $20^{\circ} \mathrm{C}, 70 \%$ RH, 16:8 L:D cycle (long day) to monitor adult emergence. As flies emerged, they were transferred into 0.5-ml Eppendorf tubes and quickly frozen. Samples were placed together with the pupae from the same collecting site in the same ultra freezer (see previous paragraph) at $-80^{\circ} \mathrm{C}$ for future genetic analysis.

\section{Statistical analyses}

All statistical analyses were run with the aid of XLSTAT version 2008.2.03 (Addinsoft, Andernach, Germany). The presence of $R$. completa in relation to the sampling site was analysed by multiple logistic regression to determine the influence of the climatic region within Switzerland, mean spring temperatures and mean winter temperatures with a single simultaneous analysis of incidence. The infestation level at the sites was measured as infestation per fruit and infestation per fruit mass (i.e. per kilogram of fruit). Both variables were analysed across all the sampled sites by simple factorial analyses of covariance (ANCOVA) to determine the influence of the factor climatic region and the covariates mean spring temperature and mean winter temperature. The same ANCOVA approach was applied to analyse the effect of the climate parameters on mean pupal weight measured in the overall samples (Appendix 1).

Data from the single fruit experiment were averaged for each site in order to avoid the inclusion of dependent data points in the analysis. They were first analysed to determine the possible influence of the climatic region, mean spring temperatures and mean winter temperatures on fruit size by simple factorial ANCOVAs. The sites where no flies were found in the experiment were excluded from the analysis. Fruit weight was $\log _{10}$ transformed in order to achieve a data structure not significantly different from the normal distribution as confirmed by Shapiro-Wilk test $(W=0.96, P=0.27)$. Subsequently, the number of pupae per fruit was also analysed by ANCOVA to determine the possible influence of the factor climatic region, the covariates mean spring temperature, mean winter temperature and fruit weight, as well as the factor mean pupal weight in a particular fruit. Finally, mean pupal weight was analysed by ANCOVA to determine the possible influence of the factor climatic region, and the covariates mean spring temperature, mean winter temperature, fruit weight and number of pupae per fruit.

The shrinking trend of the cold barrier around the Alpine divide was tested by means of a robust non-parametric correlation based on Kendall's Tau, representing the difference between the probability that in the observed data distance is reduced over time vs. the probability that time and distance behave independently.

\section{Results \\ Distribution of R. completa in Switzerland}

As detailed in fig. 1, R. completa presently occurs in most lower-altitude regions of Switzerland. Of the 71 sites in which we collected walnuts, we found infested fruit in 42 sites (52.5\% of total) distributed in 14 cantons. In the Ticino region, south of the Alpine divide, $R$. completa is fully established, as well as in the other smaller areas across the main mountain ridge towards Italy in the south-eastern parts of Switzerland (e.g. Bondo, Brusio). In the Valais, R. completa was found in the entire valley, even in the most eastern upper parts less than ten kilometres away from the Alpine divide (fig. 1). Also, in the canton Uri, $R$. completa occurs just about ten kilometres north of the Gotthard Massif forming the Alpine divide in this central region. North of that region, however, the species could not be found in the Lake Lucerne area. Along the upper Rhine Valley and its watershed, $R$. completa occurs only in the warm areas around Chur about $40 \mathrm{~km}$ north of the Alpine divide (fig. 1).

The incidence of $R$. completa in the sampling sites is significantly influenced by climate (multiple logistic regression, overall score $\left.X_{6}^{2}=34.84, P<0.0001\right)$. Among the parameters tested, however, only mean spring temperature significantly explains the incidence of $R$. completa $\left(X_{1}^{2}=8.30\right.$, $P=0.004)$, whereas climatic region $\left(X_{4}^{2}=5.40, P=0.25\right)$ and mean winter temperature $\left(X_{1}^{2}=0.013, P=0.91\right)$ had no effect. The regions where the fly is not present but the host (J. regia) is are located in the central part of the country in areas where the 30 -year mean spring temperature fluctuates between $5^{\circ} \mathrm{C}$ and about $7^{\circ} \mathrm{C}$, or falls bellow these mean values (cantons Glarus, Luzern, Nidwalden, Obwalden, Schwyz, and parts of Bern, Grisons and Jura) (Appendix 1).

\section{Infestation patterns}

Fruit infestation levels varied greatly between the sites sampled and spanned from 0 to 259.32 larvae per kilogram of fruit (Appendix 1). Although the maximum infestation levels were detected in the outskirts of the city of Bern within the central midlands of the northern pre-alpine region, heavily 


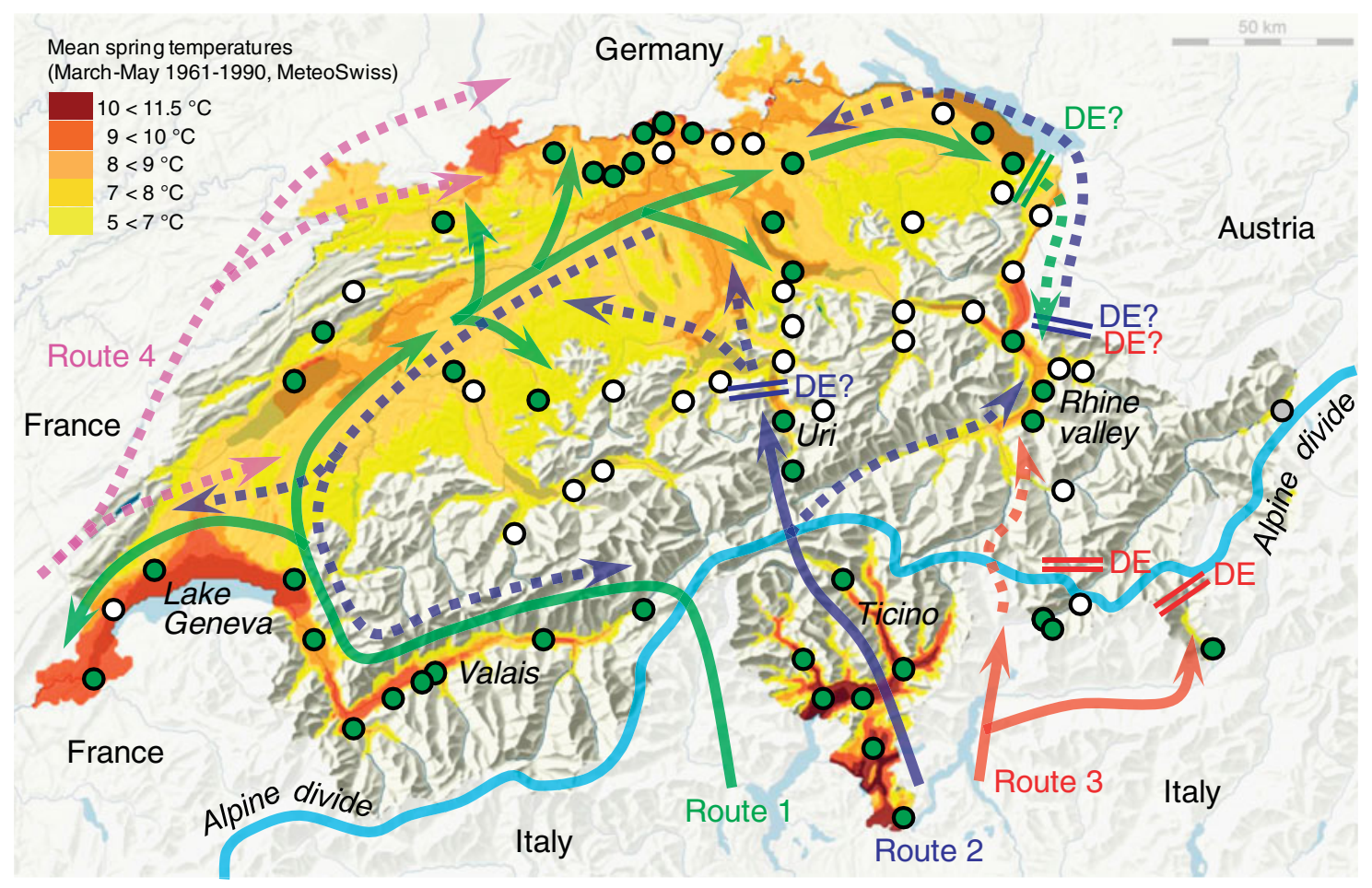

Fig. 1. Current distribution of R. completa in Switzerland with possible invasion and expansion routes. Green circles represent sites where infested fruits were collected, and white circles represent sites where fruits were collected but no infestation was determined. The grey circle represents the locality of Martina (Grisons) where no walnut trees were found despite suitable altitude and climatic conditions for tree survival. Alpine divide drawn as main physical and climatic barrier (light blue line). Four possible invasion/expansion routes are depicted: green arrows (most likely), blue (likely), pink (possible) and red (unlikely). DE, dead end (i.e. at present not yet passed physical/climatic barrier). Graphics by J. Samietz.

infested fruit was also collected in various other sites distributed all over Switzerland, such as Brusio (Grisons), Courrendin (Jura), Chur (Grisons) and Etzgen (Aargau) (details in fig. 2 and Appendix 1). The number of larvae per fruit varied between 0.08 and 9.88, averaging 1.55 for all infested samples (Appendix 1).

Infestation level per fruit was significantly influenced by mean spring temperature (ANCOVA, $F_{1,68}=4.97, P=0.029$ ). Climatic region and mean winter temperature, however, had no significant effect (ANCOVA, factor: $F_{4,68}=1.32, P=0.274$; covariate: $\left.F_{1,68}=2.70, P=0.106\right)$. Thus, the discriminating influence of spring temperature exhibits the same pattern in all climatic regions (no interaction).

Infestation rate per fruit mass was likewise significantly influenced by mean spring temperature (ANCOVA, $F_{1,68}=$ $5.49, P=0.022)$. Climatic region and mean winter temperature had no significant effect (ANCOVA, factor: $F_{4,68}=2.41$, $P=0.059$; covariate: $F_{1,68}=3.65 ; P=0.061$ ). As was the case for infestation level per fruit, the discriminating influence of spring temperature exhibits the same pattern in all climatic regions (no interaction).

The effects of seasonal temperatures on infestation level per fruit and infestation rate per fruit mass were confirmed when analysed separately. Whereas infestation by $R$. completa was not related to winter temperatures (per fruit: Spearman's $r=0.307, P=0.111$; per fruit mass: Spearman's $r=0.315$, $P=0.092)$, infestation rates were significantly correlated with spring temperatures (fig. 3a, per fruit: Spearman's $r=0.575$,
$P<0.0001$; fig. $3 \mathrm{~b}$, per fruit mass: Spearman's $r=0.577$, $P<0.0001)$.

Pupae weighed, on average, $7.66 \pm 0.21 \mathrm{mg}$ (Appendix 1) and weight was not influenced by any of the climatic parameters analysed (ANCOVA, factor climate region: $F_{4,39}=$ 0.198, $P=0.938$; covariates: spring temperature: $F_{1,39}=0.007$, $P=0.934$; winter temperature: $F_{1,39}=1.34, P=0.255$ ).

\section{Single-fruit experiment}

In the case of the subsample of walnuts that were kept individually after harvest, individual fruit weight ranged from $19.54 \mathrm{~g}$, for a nut sampled in Aigle (Vaud), to $119.2 \mathrm{~g}$, for a nut sampled in Le Guercet (Valais); but this parameter was not influenced by the climatic parameters analysed $\left(\log _{10^{-}}\right.$ transformed; ANCOVA, factor climatic region: $F_{4,159}=0.694$, $P=0.603$; covariates: spring temperature: $F_{1,159}=1.44, P=$ 0.241 ; winter temperature: $F_{1,159}=0.164, P=0.689$ ). For mean fruit mass in the samples, refer to Appendix 2.

Infestation level measured as the number of pupae per fruit was significantly influenced by individual fruit weight ( $\log _{10}$-transformed; ANCOVA, $\left.F_{1,31}=8.67, P=0.008\right)$ but not by mean pupal weight nor any of the climatic parameters analysed (ANCOVA, factor climatic region: $F_{4,31}=0.379, P=$ 0.821; covariates: spring temperature: $F_{1,31}=2.28, P=0.146$; winter temperature: $F_{1,31}=0.059, P=0.810$; pupal weight: $\left.F_{1,31}=0.016, P=0.901\right)$. The discriminating influence of fruit weight on infestation per fruit exhibits the same pattern in all 


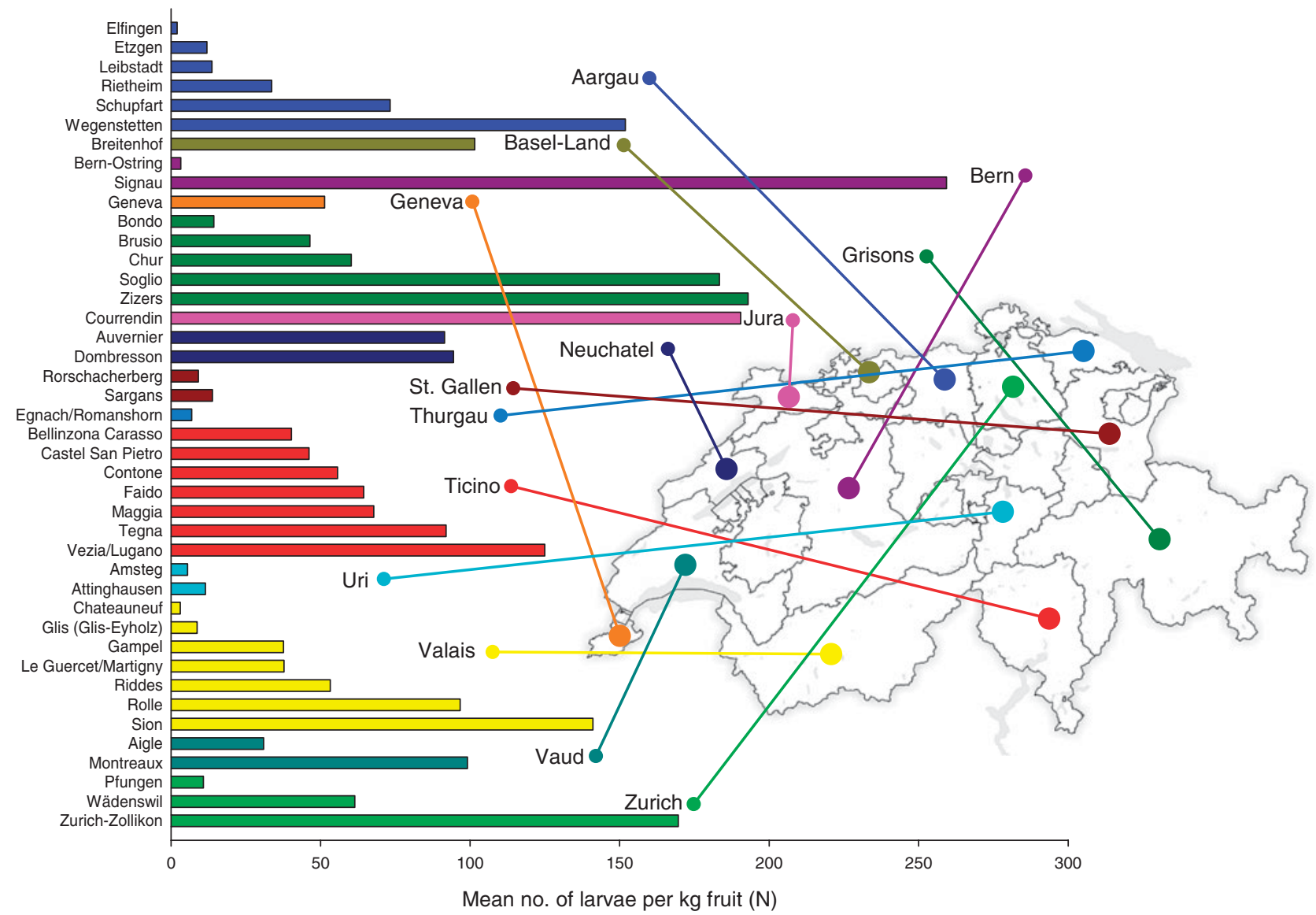

Fig. 2. Degree of infestation (larvae per kg of fruit) in infested localities across Swiss cantons, illustrating the fact that sites with the highest levels of infestation by R. completa show no discernible geographical pattern. Graphics by J. Samietz.

climatic regions (no interaction). The corresponding relationship between infestation per fruit and $\log _{10}$-transformed fruit weight is plotted in fig. 4 (for regression statistics, see graph).

Weight of single pupae in individually kept fruit varied from $4.30 \mathrm{mg}$ in Contone (Ticino) to $10.32 \pm 0.26 \mathrm{mg}$ in Bondo (Grisons), both located south of the Alpine divide (Appendix 2). Overall (considering all fruit kept individually independent of site of collection), pupae weighed a mean $7.66 \pm 0.21 \mathrm{mg}$. Importantly, pupal weight was neither influenced by individual fruit weight and pupal number per fruit nor by any of the climatic parameters analysed (ANCOVA, factor climatic region: $F_{4,31}=0.624, P=0.657$; covariates: spring temperature: $F_{1,31}=0.024, P=0.879$; winter temperature: $F_{1,31}=1.00, P=0.329$; infestation pupae per fruit: $F_{1,31}=0.0038, P=0.956$; $\log _{10}$-transformed fruit weight: $\left.F_{1,31}=3.52, P=0.559\right)$.

Based on the above, it becomes clear that there is no tradeoff between fruit size, fruit infestation level and pupal weight. To illustrate the link between the variables, pupal weight was plotted as a function of $\log _{10}$-transformed fruit size and degree of infestation in fig. 5. The nearly horizontal three-dimensional least-square mesh visualizes and confirms the ANCOVA results. That is, the smallest pupae did not stem from the most infested or smallest fruit (fig. 5).

\section{Parasitism}

A total of 6476 pupae were processed in the entire study. Of these pupae, 3675 were followed until break of diapause and adult fly emergence. In the case of the rest, we only checked for parasitoid emergence. Not a single parasitoid emerged in any case.

\section{Alpine divide as a climatic barrier}

From 1961 to 1990, in the Gotthard region of the central Swiss Alps, the width of the cold barrier around the Alpine divide, based on $\leq 7^{\circ} \mathrm{C}$ spring temperatures unsuitable for establishment of $R$. completa, was on average $43.0 \pm 26.0 \mathrm{~km}$ between the Ticino Valley (south) and the Reuss Valley (north) and $38.4 \pm 16.0 \mathrm{~km}$ between the Brenno Valley (south) and the Rhine Valley (north). In the past ten years (2001-2010), the width for the possible south-north invasion pathways shrunk to only $21.8 \pm 5.6 \mathrm{~km}$ between the Ticino and Reuss Valleys and $19.6 \pm 5.7 \mathrm{~km}$ between the Brenno and Rhine Valleys (fig. 6). During 2007, a record year with respect of spring temperatures, the shortest width was reached with only $11 \mathrm{~km}$ between sites with favourable temperatures across the Brenno and Rhine Valleys (fig. 6). The observed trend of shrinking climatic barrier is highly significant for both analysed 


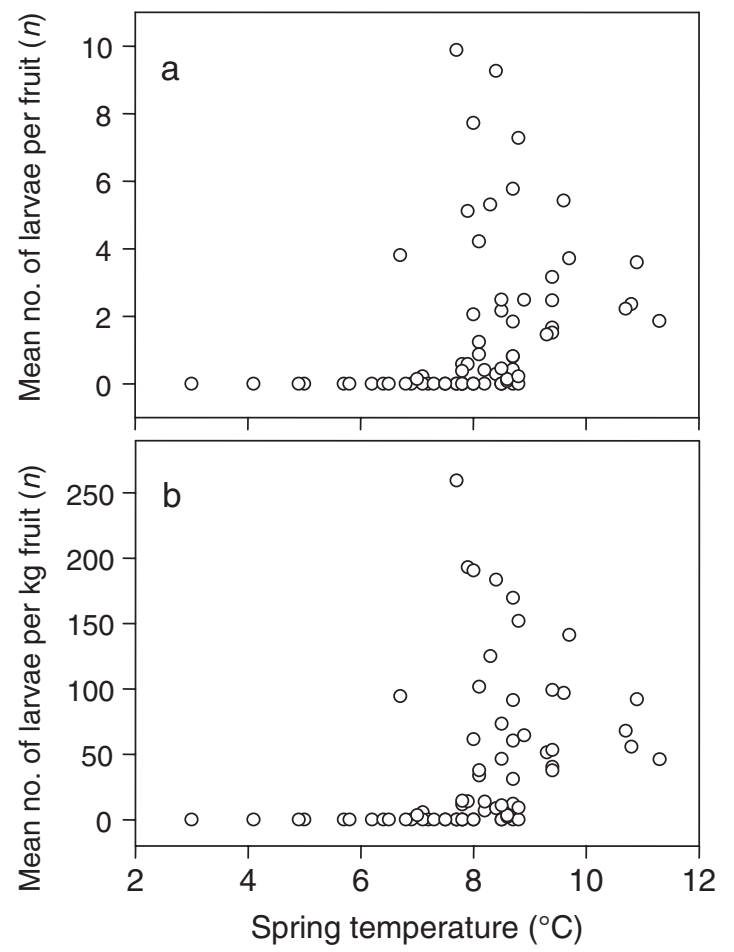

Fig. 3. Level of infestation of $R$. completa (a) per walnut fruit sampled and (b) per kilogram fruit as linear functions of meteorological 30-year averages of spring temperatures (March-May) in Switzerland on 69 locations. Refer to the text for statistics.

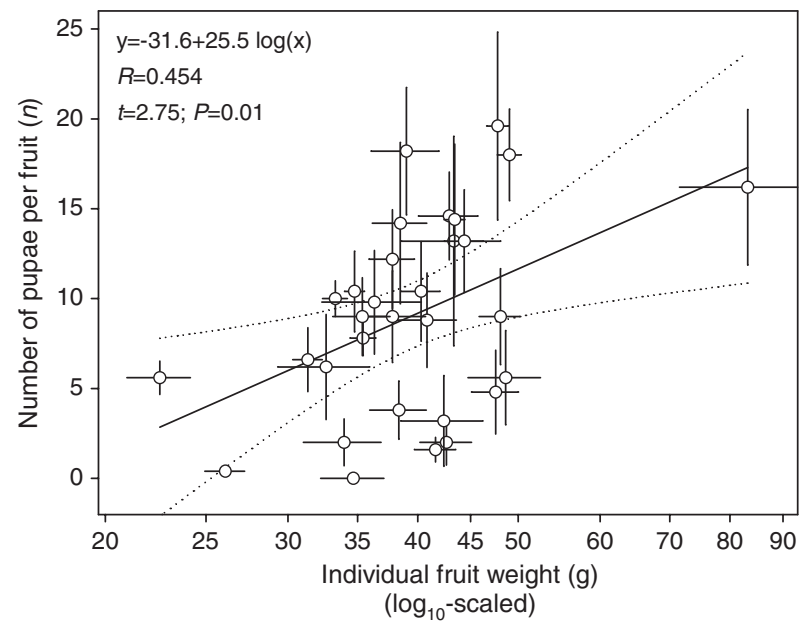

Fig. 4. Level of infestation of $R$. completa per walnut fruit as linear function of individual fruit weight in a single-fruit experiment $(n=160)$ with samples from 32 locations in Switzerland. Dashed lines: $95 \%$ confidence of the regression slope. Dotted lines: $95 \%$ confidence of the prediction range.

pathways across the Gotthard region (Ticino-Reuss Valley: Kendall's Tau $=-0.469, P<0.0001$; Brenno-Rhine Valley: Kendall's Tau $=-0.462, P<0.0001)$.

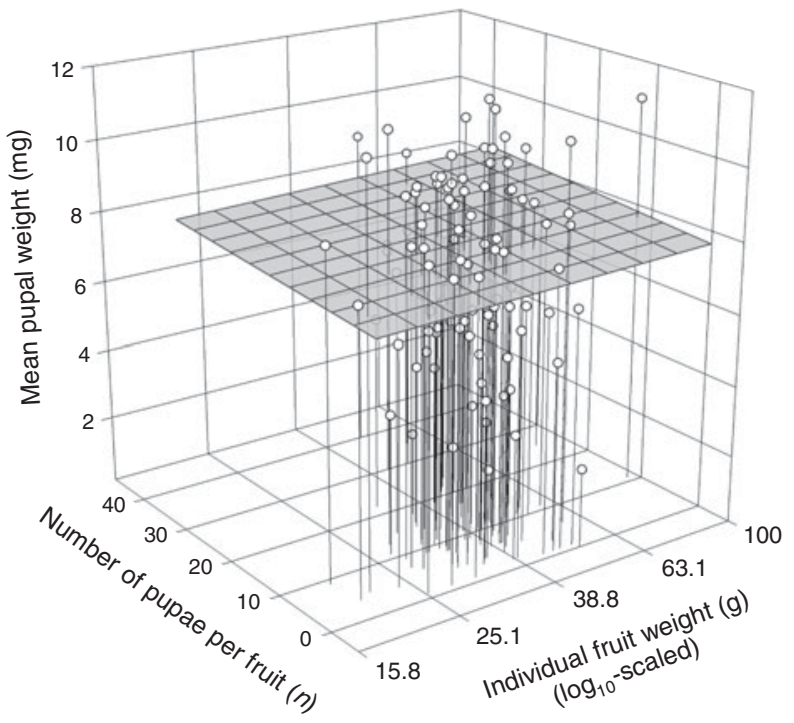

Fig. 5. Mean pupal weight of $R$. completa as multiple linear function of individual fruit weight and infestation level per walnut fruit in a single-fruit experiment $(n=160)$ with samples from 32 locations in Switzerland. Mesh shows three-dimensional least-square relationship which reveals no effect of the two parameters (for statistics see text).

\section{Discussion}

Several findings from this study merit discussion. (i) $R$. completa is now firmly established in most of Switzerland. The only areas still free of the pest are those where mean spring temperatures fall below $7^{\circ} \mathrm{C}$ or in all mountainous areas where walnut trees cannot grow. We propose factors possibly explaining its current distribution in this country and also hypothesize on possible invasion/expansion routes within Switzerland and to neighbouring countries. (ii) The sites exhibiting the highest rates of infestation are distributed all over Switzerland, with no discernible geographical pattern. (iii) We did not find a significant correlation between the degree of infestation (i.e. pupae per fruit) and pupal weight and between fruit weight and pupal weight (i.e. the smallest pupae did not stem from the most infested or smallest fruit). We discuss all the above to raise awareness on the risk of invasion of other pestiferous fruit fly species that pose potential threats, such as the apple maggot, $R$. pomonella, and other species in the same genus or, in the longer term, tropical species, such as the Medfly or the Oriental fruit fly (Meixner et al., 2002; Clarke et al., 2005).

\section{Possible invasion and expansion routes}

A recent literature review revealed that most biological invasions in Canada follow a defined pattern of introduction and spread, with some species being directly introduced but many others expanding their range from original entry points in the US (Langor et al., 2009). Identifying invasion routes becomes, therefore, a highly relevant endeavour. Incursion of invasive species from the Mediterranean across the Alps is most likely limited by the climatic limits of the species and by the orographic structure of the alpine region - especially by the Alpine divide and the main valleys. Mountain ranges 


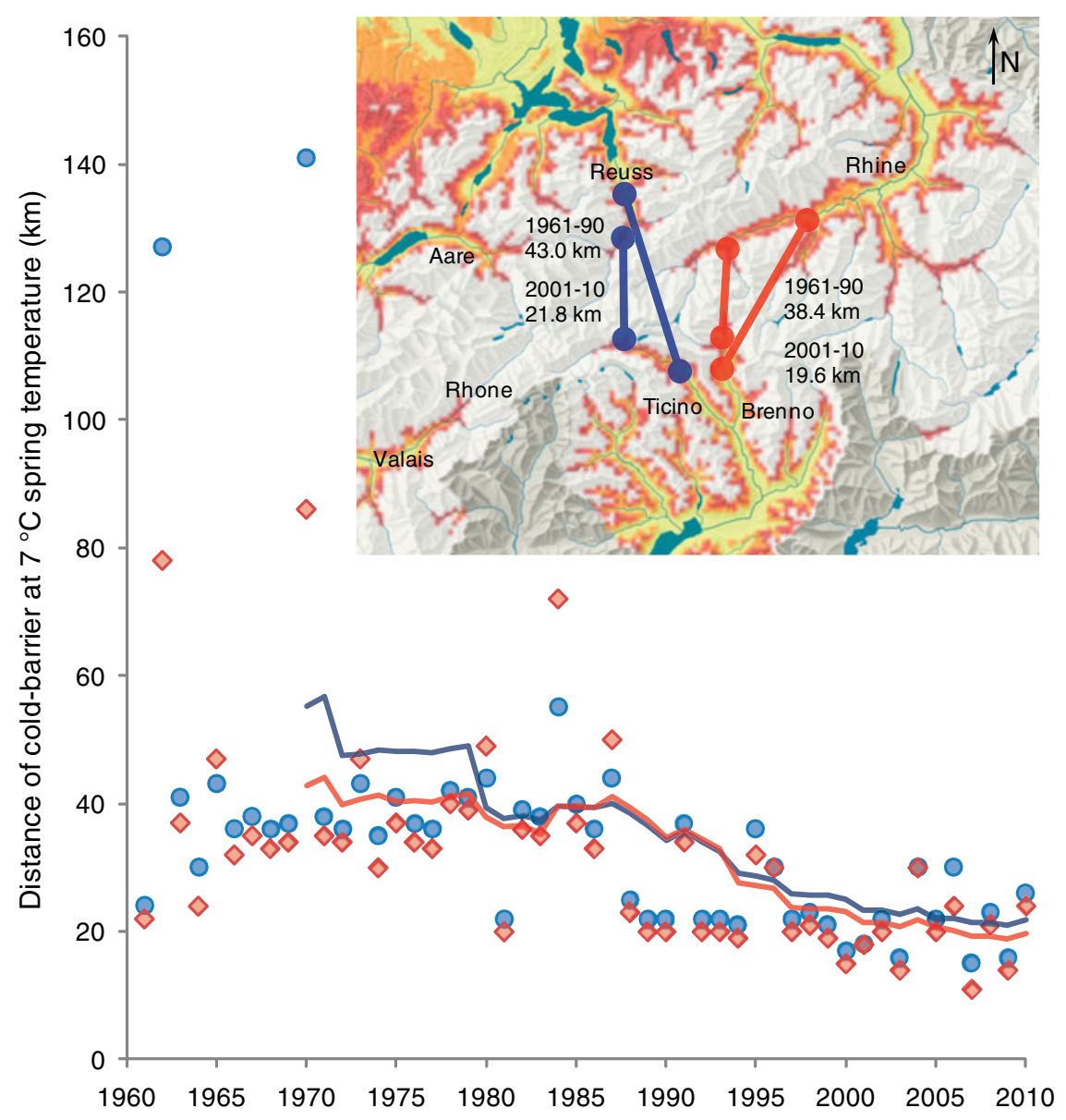

Fig. 6. Distance of cold barrier around the Alpine divide based on $7^{\circ} \mathrm{C}$ spring temperature from 1961 to 2010 for two possible south-north invasion pathways through the Gotthard region (Ticino - Reuss; Brenno - Rhine). Lines show ten-years running mean. Map insert depicts areas with mean spring temperatures for 1961-90 (yellow), 1989-2010 (orange), 2001-2010 (Red), and the record year 2007 (dark red). Graphics by J. Samietz(O, Ticino - Reuss valley; $\diamond$, Brenno - Rhine valley).

create a natural climatic and physical barrier that somehow had to be crossed by $R$. completa since it was first reported in Europe in northern Italy (Duso, 1991; Ciampolini \& Trematerra, 1992). In fig. 1, we propose four possible routes of entry of $R$. completa into Switzerland and for its expansion within the country. At this stage of the analysis, we ignore if another pathway for entry into the country could have potentially been the incidental or accidental importation of infested fruit by car. Such founder events will be explored by us in subsequent studies on the population genetics of $R$. completa since they have been found to leave genetic signatures (Berlocher, 1984; Chen et al., 2006).

Given the widespread distribution in the Valais, even in the upper valley less than ten kilometres away from the Alpine divide, a very plausible transalpine crossing point is represented by Route 1 (fig. 1; green arrows) through which adult flies would have crossed the Simplon area into the upper Valais from northern Italy. This would also be supported by Föhn winds occurring in that region that can form quite strong and warm adiabatic currents. Additionally, the Valais is a narrow valley in itself, where strong adiabatic winds that change direction during the day are generated, possibly aiding adults to quickly expand from the upper Valais towards Lake
Geneva. In both cases, flies could also have been introduced via infested fruit by nursery owners driving into the country by car.

Another very likely incursion route into the southern Ticino and plausible alpine crossing is represented by Route 2 (fig. 1; blue arrows). Adult flies likely moved into Switzerland from northern Italy along the prealpine lakes in that area (Lugano and Maggiore). Once established in the Ticino, a region where walnuts are plentiful and widespread, adult flies may have crossed the Alpine divide through the narrow Gotthard Pass into the Canton of Uri, where they could have established founder populations. Again, this may have been supported by the strong Föhn winds occurring there in the case of southern currents. From Uri, a canton where walnuts are also common in farms, backyard gardens and parks, flies could have expanded into the rest of the country via the cantons of Schwyz, Zürich, Grisons and St Gallen. Initial expansion from the Canton of Uri into northern Switzerland could have occurred via the Lake Lucerne and the Reuss Valley. We note, however, that we did not find $R$. completa directly north of Uri and in sites around Lake Lucerne. So, it is also possible that founder populations in Uri stemming from the Ticino may have disappeared after a harsh winter; and, 
if such would have been the case, Route 2 may well represent a dead end.

A third potential alpine crossing, albeit a non-parsimonious one, is represented by Route 3 (fig. 1; red arrows), where flies would have entered the Rhine Valley and its watershed from the Lake Como region in Italy via the Splügen Pass, aided by Föhn winds and then moved into St Gallen, Aargau, Schaffhausen, Basel and the Jura, Neuchâtel and Valais (opposite direction as Route 1). However, the locations in which we discovered $R$. completa populations (Chur, Zizers) are quite distant from the Alpine divide $(40 \mathrm{~km})$, and we therefore consider this hypothesis as weak. It is also possible that the flies found in western Grisons arrived via invasion routes one or two (or both).

Finally, Route 4 (fig. 1; pink arrows) would suppose that $R$. completa crossed the Alps in southern France or at least in the southernmost and, thereby, warmer parts of the Alpine divide and then would have invaded Switzerland through the Rhone valley. Although the presence of $R$. completa in France has only been recently formally acknowledged (EPPO, 2008; Bouvet, 2009), it is likely that invasion into this country occurred a long time ago and that the species is now firmly established as being the case in Switzerland. Recent invasion of the species into Germany (EPPO, 2004) likely happened by crossing the Alpine divide, either via France or more likely by one of the hypothesized routes through Switzerland. At least, the first unofficial reports of the presence of $R$. completa in Germany stem from localities in southern Baden-the tri-border region of France, Germany and Switzerland (Kirsten Köppler, personal communication). Of course, it is also possible that infested walnuts could have been carried into the country by car. In our planned genetic analysis of European populations, the genetic structure of $R$. completa populations will be analysed along the lines of Meixner et al. (2002) and Michel et al. (2007), including reference sampling in the areas of origin, to further elucidate the dynamics of the Swiss invasion.

Considering all the above, global warming over the past 50 years, and especially after 1990, appears to have facilitated the crossing of $R$. completa over the highest regions of the Swiss Alps. As analysed here, from 1985 on, there is a progressive reduction of the dividing effect around the Alpine divide (fig. 6). The ten-year running means of both pathways analysed here progressively fell from 1987 on, about the time when $R$. completa was introduced into Europe. When considering recent climate change scenarios, during the next two to three decades this climatic barrier will further shrink to mean width values of about $15 \mathrm{~km}$ (Samietz, unpublished data; IPCC, 2007). But even considering current crossing distances - on average only about $20 \mathrm{~km}$ and as little as $11 \mathrm{~km}$ in record years (e.g. 2007) - Alpine crossing aided by Föhn winds or even by active flight has become much more likely than it was only some decades ago. This should be taken into account when monitoring species establishment in the Mediterranean Basin and, thereafter, in the Alpine valleys.

The lack of a clear geographical pattern with respect to levels of infestation could be indicative of the fact that local microclimate influences larval development. However, results from the single-fruit experiment clearly indicate that fruit weight is positively correlated to infestation level by $R$. completa (fig. 4). That is, large fruit provide more resources for feeding larvae and, therefore, produce more pupae and eventually adults. Nevertheless, pupal weight, a key fitness parameter, shows no trade-off with fruit size and degree of infestation (fig. 5). That is, the smallest pupae did not necessarily stem from fruit that harboured the largest number of larvae. Therefore, we believe that the observed infestation patterns can be better explained by varying levels of secondary metabolites (allelochemicals) in fruit, in turn determined by cultivar, age of tree or by growing conditions, rather than microclimate. In support of the above, differences in walnut cultivar susceptibility to $R$. completa have been reported in California (Boyce, 1934; Hass, 1937; Opp \& Zermeño, 2001; Coates, 2005). We believe that until more accurate information on the effect of cultivar (plant chemistry) can be gathered, presence absence data, rather than infestation levels, is better suited to make inferences on potential invasion routes.

\section{Monitoring and management of invasion}

Considering the fact that two Nearctic pest species of Rhagoletis have invaded Switzerland and neighbouring countries in the past 20-30 years, preventive detection trapping for Rhagoletis pomonella a key pest of apples, $R$. indifferens a key pest of cherries, $R$. fausta a potential pest of cherries, and other Rhagoletis species in the suavis group as potential pests of walnuts should be established along probable invasion routes. An advantage, in this respect, is that all of these species are visually attracted to yellow panels, and immature adults of all species respond to ammonium carbonate (Aluja \& Rull, 2009). Therefore, a single trapping device could be employed to monitor all of these species. We also believe that if global warming trends persist, potentially allowing tropical species to survive in formerly impenetrable areas because of the presence of permanent snow or ice (and concomitant cold air), preventive trapping routes, placed along strategic valleys such as the Valais to detect the potential presence of species such as B. dorsalis, C. capitata or A. fraterculus, may be warranted.

In the USA, yellow traps baited with ammonium acetate are recommended to monitor $R$. completa populations (Riedl \& Hoying, 1981; Riedl et al., 1989). Once the first adult flies emerge, insecticides such as spinosad and malathion have been applied in California to entire tree canopies (Riedl et al., 1989; Van Steenwyk et al., 2003). An organic alternative to insecticides applied in California is represented by clay-based kaolin products (e.g. Surround ${ }^{\circledR}$ ) (Coates \& Van Steenwyk, 2002). Among the European countries recently invaded by $R$. completa, France, a country with large commercial walnutproducing areas, has approved the restricted use (limit of 120 days) of thiacloprid and phosmet for conventional agriculture and spinosad for organic nut production in 2009 (guidelines of EU Directive 2000/29, Annex A) (Bouvet, 2009).

The potential danger $R$. completa represents to peach growers in Central Europe is a topic that merits attention. This fly has been shown to attack peaches in California, where, fortunately, its diapause schedule causes it to emerge at the end of the peach harvest season, allowing for the implementation of a 'pest-free harvest period' (Yokoyama \& Miller, 1993, 1994). Nevertheless, it has to be kept in mind that plasticity in diapause length facilitated expansion of $R$. completa from its native range in the midwestern US $\left(5^{\circ} \mathrm{C}\right)$ to California, where warmer winter temperatures prevail $\left(10^{\circ} \mathrm{C}\right)$ (Chen et al., 2006). R. completa may possess the genetic variability necessary to evolve diapause lengths to match the fruiting phenology of potential European host plants. We, therefore, suggest the establishment of a preventive monitoring network to help reduce the potential danger posed by $R$. completa to peach growers in Hungary and Romania, 
as this species has already been detected in Austria and Slovenia (Seljak, 1999; Lethmayer, 2008).

\section{Insights into the biology and ecology of Rhagoletis completa}

Our study yielded many insights into the biology and ecology of this invasive pest and complements nicely the work of pioneers such as Cresson (1929) and Boyce (1934) (for a more recent review see Prokopy \& Papaj, 2000). For example, quantitative data on rates of infestation were retrieved (e.g. larvae per fruit), which in turn shed light into the oviposition behaviour of females, which, as far as is known, lay one egg per oviposition bout but commonly reuse previously used oviposition punctures. Our findings coincide with those of Papaj (1994) and Nufio et al. (2000) who, working with other walnut infesting species ( $R$. boycei and R. juglandis), also report the presence of multiple larvae per fruit, the result of multiple ovipositions by the same female or conspecifics. Our discoveries on the close temperature relationship between $R$. completa and sites where it is present expand our knowledge on the ecology of this tephritid fly, as previously pointed out by Chen et al. (2006) in California for introduced populations of $R$. completa and by Filchak et al. (2000) for host races of $R$. pomonella. This is important, as gene-environment interactions related to the effect of local environment and host phenology can produce genetically differentiated populations adjusted to different hosts (Berlocher, 1984).

As is common with invasive species (Torchin et al., 2003), we found that parasitism is currently nil in Switzerland. That is, the pest escaped from an important mortality factor, at least for a while. Previously, Feder (1995), working with the apple maggot, $R$. pomonella, documented the fact that, by shifting hosts (from the native hawthorn (Crataegus mollis (Torr. \& A. Gray) Scheele) to the introduced apple (Malus domestica Borkh.)), the degree of parasitism fell from a mean of $46 \%$ to a mean of $13 \%$. Similarly, $R$ completa is attacked by Aganaspis alujai in its native range, while no parasitoids have ever been recorded in association with this species in California (Boyce, 1934; Legner \& Goeden, 1987; Ovruski et al., 2007).

In conclusion, we were not only able to firmly establish the current distribution of $R$. completa in Switzerland but gained significant insights into its biology and ecology, which will become handy when management schemes in the invaded European countries have to be designed. Additionally, our findings here highlight the rapid pace with which Rhagoletis pest species of Neartic origin can establish and expand within Europe with perhaps global warming allowing crossing of the Alps much more rapidly than it was the case some decades ago. Rhagoletis cingulata is supposed to have a similar invasive history as $R$. completa and currently is becoming a nuisance in sour-cherry growing regions of Germany and neighbouring countries (K. Köppler, personal communication). Considering current global warming trends and particularly the ever increasing volume of international trade, additional invasions represent a realistic potential threat that should be taken seriously (Work et al., 2005). Therefore, identifying potential entry routes, climate parameters promoting or hindering expansion, potential host species, better understanding of environmental resilience to invasive species and prospecting remedial measures should become a high priority to minimize potential damage to fruit production in European countries by other potentially invasive fruit fly species.

\section{Acknowledgements}

We thank all walnut tree owners that granted us permission to collect samples throughout Switzerland and gratefully acknowledge Patrizia and Tobias Eichelberg, Christina Marazzi, Rahel and Peter Überschlag, Barbara and Steve Leib and Betty Benrey for facilitating the identification of collection sites and arranging permissions by walnut-tree owners to collect samples. We also thank Luigi Colombi (LC), Mauro Genini (MG) and Patrick Kehrli (PK) for helping us collect samples in the entire Ticino (LC), the middle and lower Valais (MG) and Nyon and Geneva (PK). We thank Neil Villard for guiding us through the Jura region and Kathrin Annaheim, Hans Ulrich Höpli and Elizabeth Razavi for expert technical support and Alberto Anzures Dadda and Suzzette Tamez-Cruz for helping us prepare the final version of this manuscript. Financial support was furnished by the Mexican Council for Science and Technology (CONACyT) through a competitive Sabbatical Year Fellowship to MA (Reference No. 79449), and a competitive Research Grant to JR (Reference No. CB 2005-25889-50008Q), by Aline Schünemann who provided a rental car to travel throughout most of Switzerland, by Agroscope Changins-Wädenswil ACW (internal funds managed by JS) and by the Instituto de Ecología, A.C. (salaries of MA and LG). MA would like to thank the Agroscope Changins-Wädenswil ACW for allowing him and his family to live in the guest house and for providing laboratory facilities and administrative support during his Sabbatical. We also thank two anonymous reviewers and the editor for constructive comments.

\section{References}

Aluja, M. \& Mangan, R. L. (2008) Fruit fly (Diptera: Tephritidae) host status determination: critical conceptual, methodological, and regulatory considerations. Annual Review of Entomology 53, 473-502.

Aluja, M. \& Rull, J. (2009) Managing pestiferous fruit flies (Diptera: Tephritidae) through environmental manipulation. pp. 171-213 in Aluja, M., Leskey, T.C. \& Vincent, C. (Eds) Biorational Tree-Fruit Pest Management. Wallingford, UK, CABI.

Aschwanden, A., Beck, M., Häberli, C., Haller, G., Kiene, M., Roesch, A., Sie, R. \& Stutz, M. (1996) Die Ergebnisse des Projekts KLIMA90, Grafiken. Schweizerische Meteorologische Anstalt (MeteoSchweiz), Zürich.

Begert, M., Schlegel, T. \& Kirchhofer, W. (2005) Homogeneous Temperature and Precipitation Series of Switzerland from 1864 to 2000. International Journal of Climatology 25, 65-80.

Berlocher, S. H. (1984) Genetic changes coinciding with the colonization of California by the walnut husk fly, Rhagoletis completa. Evolution 38, 906-918.

Bouvet, G. (2009) La filière noix du Sud-Est fait face à la mouche du brou. L'Arboriculture 636, 24-26.

Boyce, A. M. (1934) Bionomics of the walnut husk fly, Rhagoletis completa. Hilgardia 8, 363-579.

Bush, G. L. (1966) The taxonomy, cytology, and evolution of the genus Rhagoletis in North America (Diptera: Tephritidae). Bulletin of the Museum of Comparative Zoology 134, 431-562.

Cannon, R. J. C. (1998) The implications of predicted climate change for insect pests in the UK, with emphasis on nonindigenous species. Global Change Biology 4, 785-796.

Chapman, J. W., Reynolds, D. R., Smith, A. D., Smith, E. T. \& Woiwod, I. P. (2004) An aerial netting study of insects 
migrating at high altitude over England. Bulletin of Entomological Research 94, 123-136.

Chen, Y. H., Opp, S. B., Berlocher, S. H. \& Roderick, G. K. (2006) Are the bottlenecks associated with colonization? Genetic diversity and diapause variation of native and introduced Rhagoletis completa populations. Oecologia 149, 656-667.

Ciampolini, M. \& Trematerra, P. (1992) Widespread occurrence of walnut fly (Rhagoletis completa Cresson) in northern Italy. Informatore Agrario 48, 52-56.

Clarke, A. R., Armstrong, K. F., Carmichael, A. E., Milne, J. R., Raghu, S., Roderick, G. K. \& Yeates, D. K. (2005) Invasive phytophagous pests arising through a recent tropical evolutionary radiation: The Bactrocera dorsalis complex of fruit flies. Annual Review of Entomology 50, 293-319.

Coates, W.W. (2005) Walnut husk fly: varietal susceptibility and its impact in nut quality. pp. 157-160 in Walnut Research Reports. Walnut Marketing Board, Sacramento, CA, USA.

Coates, W. W. \& Van Steenwyk, R. A. (2002) Evaluation of Kaolin (Surround) for walnut husk fly (Rhagoletis completa) control in English walnuts. Walnut Research Reports. Available online at http://walnutresearch.ucdavis.edu/2002/2002_375.pdf (accessed 3 June 2010).

Cresson, E. T. Jr (1929) A revision of the North American species of fruit flies of the genus Rhagoletis (Diptera: Trypetidae). Transactions of the American Entomological Society 55, 401-414.

Drew, R. A. I., Tsuruta, K. \& White, I. M. (2005) A new species of pest fruit fly (Diptera: Tephritidae: Dacinae) from Sri Lanka and Africa. African Entomologist 3, 149-154.

Dukes, J. S. \& Mooney, H. A. (1999) Does global change increase the success of biological invaders? Trends in Ecology and Evolution 14, 135-139.

Duso, C. (1991) Sulla comparsa in Italia di un Tefritide neartico del noce Rhagoletis completa Cresson (Diptera: Tephritidae). Bolletino da Zoologia Agraria Bachicoltura 23, 203-209.

Duso, C. \& Dal Lago, G. (2006) Life cycle, phenology and economic importance of the walnut husk fly Rhagoletis completa Cresson in northern Italy. Annales de la Societé Entomologique de France 42, 245-254.

Duyck, P. F., David, P. \& Quilici, S. (2004) A review of relationships between interspecific competition and invasions in fruit flies (Diptera: Tephritidae). Ecological Entomology 29, 511-520.

EPPO (2004) Ocurrence of Rhagoletis completa in Germany. Reporting Service 2004 of the European and Mediterranean Plant Protection Organization, no. 09.

EPPO (2008) Premier signalement de Rhagoletis completa en France. Reporting Service 2008 of the European and Mediterranean Plant Protection Organization, no. 12.

EPPO/CABI (1996) Rhagoletis spp. (non European). pp. 265-274 in Smith, I.M., McNamara, D.G., Scott, P.R., \& Harris, K.M. (Eds) Quarantine Pests for Europe. Wallingford, UK, CABI.

Feder, J. L. (1995) The effect of parasitoids on sympatric host races of Rhagoletis pomonella (Diptera: Tephritidae). Ecology 76, 801-813.

Filchak, K. E., Roethele, J. B. \& Feder, J. L. (2000) Natural selection and sympatric divergence in the apple maggot Rhagoletis pomonella. Nature 407, 739-742.

Hass, A. R. C. (1937) Factors in varietal susceptibility of walnut fruits to attack by the walnut husk fly. Plant Physiology 12, 721-736.

Hernández-Ortíz, V. (1985) Descripción de una nueva especie Mexicana del género Rhagoletis Loew (Diptera: Tephritidae). Folia Entomologica Mexicana 64, 73-79.
Hislop, R. G. \& Allen, W. W. (1983) Correlation of walnut husk fly activity, larval infestation period and hasrvest quality of early-mid- and late-maturing walnut varieties. pp. 42-52 in Walnut Research Reports. Walnut Marketing Board, Sacramento, CA, USA.

IPCC (2007) Climate Change 2007: Synthesis Report. Intergovernmental Panel on Climate Change, Geneva.

Kasana, A. \& AliNiazee, M. T. (1995) Adult flight dynamics of walnut husk fly (Diptera: Tephritidae) in the Willamette Valley of Oregon. Pan-Pacific Entomologist 71, 142-148.

Kasana, A. \& AliNiazee, M. T. (1996) Seasonal phenology of the walnut husk fly, Rhagoletis completa Cresson (Diptera: Tephritidae). Canadian Entomologist 128, 377-390.

Kenis, M. (2006) Insects. pp. 71-100 in Wittenberg, R. (Ed.) Invasive Alien Species in Switzerland. An Inventory of Alien Species and Their Threat to Biodiversity and Economy in Switzerland. Environmental Studies, vol 29, no. 6. Geneva, Swiss Federal Office for the Environment.

Kenis, M., Auger-Rozenberg, M. A., Roques, A., Timms, L., Péré, C., Cock, M. J. W., Settele, J., Augustin, S. \& Lopez-Vaamonde, C. (2009) Ecological effects of invasive alien insects. Biological Invasions 11, 21-45.

Langor, D. W., DeHaas, L. J. \& Foottit, R. G. (2009) Diversity of non-native terrestrial arthropods on woody plants in Canada. pp. 5-19 in Langor, D.W. \& Sweeney, J. (Eds) Ecological Impacts of Non-Native Invertebrates and Fungi on Terrestrial Ecosystems. Dordrecht, The Netherlands, Springer.

Lampe, I., Burghause, F. \& Krauthausen, H. J. (2005) Introduction and distribution of the American eastern cherry fruit fly, Rhagoletis cingulata, in the Rhine Valley, Germany. pp. 135-140 in Alford, D.V. \& Backhaus, G.F. (Eds) Proceedings of Plant Protection and Plant Health in Europe: Introduction and Spread of Invasive Species. Humboldt University, 9-11 June 2005. Berlin, Germany.

Legner, E. F. \& Goeden, D. (1987) Larval parasitism of Rhagoletis completa (Diptera: Tephritidae) on Juglans microcarpa (Juglandaceae) in western Texas and southeastern New Mexico. Proceedings of the Entomological Society of Washington 89, 739-743.

Lethmayer, C. (2008) First evidence of the walnut husk fly (Rhagoletis completa) in Austria. In International Conference on Integrated Fruit Production, Abstracts, 86. IOBC wprs. Avignon, France.

Mack, R. N., Simberloff, D., Lonsdale, W. M., Evans, H., Clout, M. \& Bazzaz, F. A. (2000) Biotic invasions: causes, epidemiology, global consequences, and control. Ecological Applications 10, 689-710.

Mani, E., Merz, B., Brugnetti, R., Schaub, L., Jermini, M. \& Schwaller, F. (1994) Zum Auftreten der beiden amerikanischen Früchtfliegenarten Rhagoletis completa Cresson und Rhagoletis indifferens Curran in der Schweiz (Diptera: Tephritidae). Mitteilungen der Schweizerischen Entomologischen Gesellschaft 67, 177-182.

Merz, B. (1991) Rhagoletis completa Cresson und Rhagoletis indifferens Curran zwei wirtschaftlich bedeutende nordamerikanische Früchtfliegen, neu für Europa (Diptera: Tephritidae). Mitteilungen der Schweizerischen Entomologischen Gesellschaft 64, 55-57.

Merz, B. \& Niehuis, M. (2001) Remarkable records of fruit flies (Diptera, Tephritidae) from Rhineland-Palatinate (Germany). Dipteron 4, 57-64.

Meixner, M. D., McPheron, B. A., Silva, J. G., Gasparich, G. E. \& Sheppard, W. S. (2002) The Mediterranean fruit fly in California: evidence for multiple introductions and 
persistent populations based on microsatellite and mitochondrial DNA variability. Molecular Ecology 11, 891-899.

Michel, A., Rull, J., Aluja, M. \& Feder, J. L. (2007) The genetic structure of hawthorn-infesting Rhagoletis pomonella populations in Mexico: implications for sympatric host race formation. Molecular Ecology 16, 2867-2878.

Mooney, H. A. \& Hobbs, R. J. (2000) Global change and invasive species: Where do we go from here? pp. 425-435 in Mooney, H.A. \& Hobbs, R.J. (Eds) Invasive Species in a Changing World. Washington DC, USA, Island Press.

Müller, G. (1980) Die Beobachtungsnetze der Schweizerischen Meteorologischen Anstalt. Arbeitsberichte der Schweizerischen Meteorologischen Anstalt 93, 1-66.

Mumford, J. D. (2002) Economic issues related to quarantine in international trade. European Review of Agricultural Econonomics 29, 329-348.

Norrbom, A. L. (2004) Host plant database for Anastrepha and Toxotrypana (Diptera: Tephritidae: Toxotrypanini). Diptera Data Dissemination Disk (CD-ROM vol. 2).

Nufio, C. R., Papaj, D. R. \& Alonso-Pimentel, H. (2000) A field analysis of host fruit utilization by the walnut fly, Rhagoletis juglandis. Environmental Entomology 93, 994-1001.

Olhendorf, B. (2000) Walnut husk fly: Integrated Pest Management in the home garden. Pest Notes, Publication 7430. Davis, CA, University of California.

Opp, S. \& Zermeño, J. (2001) Timing and susceptibility of walnut cultivars to walnut husk fly attack - episode 2. pp. 293-295 in Walnut Research Reports 2000. Sacramento, CA, Walnut Marketing Board.

Ovruski, S., Wharton, R., Rull, J. \& Guillen, L. (2007) Aganaspis alujai (Hymenoptera: Figitidae: Eucoilinae), a new species attacking Rhagoletis (Diptera: Tephritidae) in the neotropical region. Florida Entomologist 90, 626-634.

Papaj, D. R. (1994) Oviposition site guarding by male walnut flies and its possible consequences for mating success. Behavioral Ecology and Sociobiology 34, 187-195.

Pimentel, D., Lach, L., Zuniga, R. \& Morrison, D. (2000) Environmental and economic costs of nonindigenous species in the United States. Bioscience 50, 53-65.

Primack, R. B., Ibanez, I., Higuchi, H., Lee, S. D., Miller-Rushing, A. J., Wilson, A. M. \& Silander, J. A. (2009) Spatial and interspecific variability in phenological responses to warming temperatures. Biological Conservation 142, 2569-2577.

Prokopy, R. J. \& Papaj, D. (2000) Behavior of flies of the genera Rhagoletis, Zonosemata and Carpomya (Trypetinae: Carpomyina). pp. 219-252 in Aluja, M. \& Norrbom, A.L. (Eds) Fruit Flies (Tephritidae): Phylogeny and Evolution of Behavior. Boca Raton, FL, USA, CRC Press.

Ricciardi, A. (2007) Are modern biological invasions an unprecedented form of global change? Conservation Biology 21, 329-336.

Riedl, H. \& Hoying, S. A. (1981) Evaluation of trap designs and attractants for monitoring the walnut husk fly, Rhagoletis completa Cresson (Diptera: Tephritidae). Zeitschrift fur Angewandte Entomologie 91, 510-520.
Riedl, H., Barnett, W. W., Coates, W. W., Coviello, R., Joos, J. \& Olson, W. H. (1989) Walnut husk fly (Diptera: Tephritidae): evaluation of traps for timing of control measures and for damage predictions. Journal of Economic Entomology 82, 1191-1196.

Roll, U., Dayan, T. \& Simberloff, D. (2007) Non-indigenous insect species in Israel and adjacent areas. Biological Invasions 9, 629-643.

Rosati, J. Y. \& Van Laerhoven, S. L. (2007) New record of Chrysomya rufifacies (Diptera: Calliphoridae) in Canada: predicted range expansion and potential effects on native species. Canadian Entomologist 139, 670-677.

Seljak, G. (1999) Orehova muha (Rhagoletis completa Cresson) - nov nevaren skodljivec orehov v Sloveniji. Revija za Sadjarstvo Vinogradnistvo in Vinarstvo 10, 12-15.

Smith, J. \& Bush, G. L. (2000) Phylogeny of the subtribe Carpomyina (Trypetinae), emphasizing relationships of the genus Rhagoletis. pp. 187-217 in Aluja, M. \& Norrbom, A. (Eds) Fruit Flies (Tephritidae): Phylogeny and Evolution of Behavior. Boca Raton, FL, USA, CRC Press.

Studer, S., Appenzeller, C. \& Defila, C. (2005) Inter-annual variability and decadal trends in Alpine spring phenology: a multivariate analysis approach. Climate Change 73, 395-414.

Swiss Federal Council (2001) Verordnung über Pflanzenschutz (Pflanzenschutzverordnung, PSV). German version of 28 February 2001 (status as of 15 November 2009). Compilation of Swiss Federal Legislation SR 916.20, Bern.

Torchin, M. D., Lafferty, K. D., Dobson, A. P., McKenzie, V. J. \& Kuris, A. M. (2003) Introduced species and their missing parasites. Nature 421, 628-630.

Torrez-Diaz, C., Cavieres, L. A., Munoz-Ramirez, C. \& Arroyo, M. T. K. (2007) Consequences of microclimate variation on insect pollinator visitation in two species of Chaetanthera (Asteraceae) in the central Chilean Andes. Revista Chilena de Historia Natural 80, 455-468.

Van Steenwyk, R. A., Zolbrod, S. K. \& Nomoto, R. M. (2003) Walnut husk fly control with reduced risk insecticides. pp. 369-374 in Proceedings of the 77th Annual Western Orchard Pest \& Disease Management Conference. Portland, OR, 15-17 January 2003. Pullman, Washington State University.

Westphal, M. I., Browne, M., MacKinnon, K. \& Noble, I. (2008) The link between international trade and the global distribution of invasive alien species. Biological Invasions 10, 391-398.

Work, T. T., McCullough, D. G., Cavey, J. F. \& Komsa, R. (2005) Arrival rate of nonindigenous insect species into the United States through foreign trade. Biological Invasions 7, 323-332.

Yokohama, V. Y. \& Miller, G. T. (1993) Pest free period for walnut husk fly (Diptera: Tephritidae) and host status of stone fruits for export to New Zealand. Journal of Economic Entomology 86, 1766-1772.

Yokoyama, V. Y. \& Miller, G. T. (1994) Walnut husk fly (Diptera: Tephritidae) pest free and preovipositional periods and adult emergence for stone fruits exported to New Zealand. Journal of Economic Entomology 87, 747-751. 


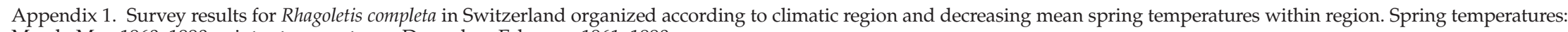
March-May 1960-1990; winter temperatures: December-February 1961-1990.

\begin{tabular}{|c|c|c|c|c|c|c|c|c|c|c|c|}
\hline \multirow[t]{2}{*}{ Locality } & \multirow[t]{2}{*}{ Canton } & \multirow{2}{*}{$\begin{array}{l}\text { Climate } \\
\text { Region }\end{array}$} & \multicolumn{2}{|c|}{$\begin{array}{c}\text { Temperature } \\
\left({ }^{\circ} \mathrm{C}\right)\end{array}$} & \multirow[t]{2}{*}{$\begin{array}{l}\text { Sampling } \\
\text { date }\end{array}$} & \multicolumn{2}{|c|}{$\begin{array}{l}\text { Quantity/ } \\
\text { No. Fruits }\end{array}$} & \multirow[t]{2}{*}{ Infestation } & \multicolumn{2}{|c|}{$\begin{array}{l}\text { Mean No. } \\
\text { larvae per }\end{array}$} & \multirow[t]{2}{*}{$\begin{array}{l}\text { Mean pupal } \\
\text { weight (mg) }\end{array}$} \\
\hline & & & Spring & Winter & & Mass (kg) & No. & & Fruit & kg Fruit & \\
\hline Tegna & Ticino & Alps south & 11.3 & 4.3 & 8 Sep 08 & 3.898 & 97 & Yes & 1.86 & 46.18 & 6.77 \\
\hline Bellinzona Carasso & Ticino & Alps south & 10.9 & 2.7 & 8 Sep 08 & 2.110 & 54 & Yes & 3.59 & 91.94 & 8.40 \\
\hline Contone & Ticino & Alps south & 10.8 & 2 & 8 Sep 08 & 3.805 & 90 & Yes & 2.36 & 55.72 & 7.16 \\
\hline Vezia/Lugano & Ticino & Alps south & 10.7 & 2.8 & 8 Sep 08 & 3.199 & 98 & Yes & 2.21 & 67.83 & 7.48 \\
\hline Castel San Pietro & Ticino & Alps south & 9.4 & 0.6 & 8 Sep 08 & 1.937 & 47 & Yes & 1.66 & 40.27 & 9.80 \\
\hline Maggia & Ticino & Alps south & 8.9 & 3.5 & 8 Sep 08 & 3.772 & 98 & Yes & 2.48 & 64.42 & 6.32 \\
\hline Bondo & Grisons & Alps south & 8.7 & -1.7 & 30 Aug 08 & 2.588 & 85 & Yes & 1.84 & 60.28 & 7.47 \\
\hline Faido & Ticino & Alps south & 8.3 & 0.6 & 8 Sep 08 & 3.225 & 76 & Yes & 5.30 & 124.96 & 10.44 \\
\hline Brusio & Grisons & Alps south & 7.9 & 0.5 & 30 Aug 08 & 2.197 & 83 & Yes & 5.11 & 192.99 & 8.85 \\
\hline Soglio & Grisons & Alps south & 7.8 & -4.5 & 30 Aug 08 & 1.885 & 72 & Yes & 0.38 & 14.32 & 9.75 \\
\hline Vicosoprano & Grisons & Alps south & 3 & -2.9 & 20 Sep 08 & 0.352 & 10 & No & 0.00 & 0.00 & \\
\hline Sargans & St. Gallen & Alps north & 8.8 & 0.5 & 24 Sep 08 & 0.548 & 23 & Yes & 0.22 & 9.12 & \\
\hline Zizers & Grisons & Alps north & 8.5 & 0.3 & 24 Sep 08 & 1.873 & 35 & Yes & 2.49 & 46.45 & 9.63 \\
\hline Chur & Grisons & Alps north & 8.4 & 0.1 & 24 Sep 08 & 2.121 & 42 & Yes & 9.26 & 183.40 & 8.78 \\
\hline Grabs & St. Gallen & Alps north & 8 & 1.4 & 24 Sep 08 & 0.972 & 25 & No & 0.00 & 0.00 & \\
\hline Walenstadt & St. Gallen & Alps north & 8 & 1 & 24 Sep 08 & 0.794 & 33 & No & 0.00 & 0.00 & \\
\hline Attinghausen & Uri & Alps north & 7.8 & 1 & 23 Sep 08 & 1.218 & 24 & Yes & 0.58 & 11.49 & 11.04 \\
\hline Ingenbohl, Brunnen & Schwyz & Alps north & 7.8 & 0.9 & 23 Sep 08 & 0.996 & 20 & No & 0.00 & 0.00 & \\
\hline Näfels & Glarus & Alps north & 7.8 & 0 & 24 Sep 08 & 0.853 & 26 & No & 0.00 & 0.00 & \\
\hline Schiers (dir. Landquart) & Grisons & Alps north & 7.8 & -0.5 & 24 Sep 08 & 1.274 & 36 & No & 0.00 & 0.00 & \\
\hline Muri & Bern & Alps north & 7.7 & 0 & 23 Sep 08 & 1.463 & 38 & No & 0.00 & 0.00 & \\
\hline Interlaken & Bern & Alps north & 7.7 & -0.2 & 8 Oct 08 & 0.833 & 50 & No & 0.00 & 0.00 & \\
\hline Stans & Nidwalden & Alps north & 7.5 & 2.6 & 23 Sep 08 & 1.089 & 29 & No & 0.00 & 0.00 & \\
\hline Sarnen, Föribach & Obwalden & Alps north & 7.3 & 2.3 & 7 Oct 08 & 1.022 & 34 & No & 0.00 & 0.00 & \\
\hline Glarus & Glarus & Alps north & 7.2 & -0.4 & 24 Sep 08 & 0.920 & 24 & No & 0.00 & 0.00 & \\
\hline Lüchingen & St. Gallen & Alps north & 7.1 & 1.4 & 24 Sep 08 & 1.246 & 28 & No & 0.00 & 0.00 & \\
\hline Amsteg & Uri & Alps north & 7.1 & 1.2 & 23 Sep 08 & 0.908 & 23 & Yes & 0.22 & 5.51 & 5.78 \\
\hline Signau & Bern & Alps north & 7 & -0.5 & 23 Sep 08 & 1.223 & 29 & Yes & 0.14 & 3.27 & 8.10 \\
\hline Kien & Bern & Alps north & 6.9 & -0.2 & 8 Oct 08 & -1 & - & No & - & - & \\
\hline Niederried/Interlaken & Bern & Alps north & 6.8 & -1.1 & 8 Oct 08 & 1.235 & 63 & No & 0.00 & 0.00 & \\
\hline Schüpfheim & Luzern & Alps north & 6.4 & 0.8 & 23 Sep 08 & 0.808 & 21 & No & 0.00 & 0.00 & \\
\hline Sattel & Schwyz & Alps north & 5.8 & -1.3 & 23 Sep 08 & 0.864 & 21 & No & 0.00 & 0.00 & \\
\hline Maria/Schiers & Grisons & Alps north & 5.7 & -2.3 & 24 Sep 08 & 0.384 & 16 & No & 0.00 & 0.00 & \\
\hline Martina & Grisons & Alps north & 5.2 & -3.5 & 30 Sep 08 & $-{ }^{2}$ & - & No & - & - & \\
\hline Surava & Grisons & Alps north & 4.9 & -0.4 & 30 Aug 08 & 0.032 & 1 & No & 0.00 & 0.00 & \\
\hline
\end{tabular}


Appendix 1. (Cont.)

\begin{tabular}{|c|c|c|c|c|c|c|c|c|c|c|c|}
\hline \multirow[t]{2}{*}{ Locality } & \multirow[t]{2}{*}{ Canton } & \multirow{2}{*}{$\begin{array}{l}\text { Climate } \\
\text { Region }\end{array}$} & \multicolumn{2}{|c|}{$\begin{array}{c}\text { Temperature } \\
\left({ }^{\circ} \mathrm{C}\right)\end{array}$} & \multirow[t]{2}{*}{$\begin{array}{l}\text { Sampling } \\
\text { date }\end{array}$} & \multicolumn{2}{|c|}{$\begin{array}{l}\text { Quantity/ } \\
\text { No. Fruits }\end{array}$} & \multirow[t]{2}{*}{ Infestation } & \multicolumn{2}{|c|}{$\begin{array}{l}\text { Mean No. } \\
\text { larvae per }\end{array}$} & \multirow[t]{2}{*}{$\begin{array}{l}\text { Mean pupal } \\
\text { weight (mg) }\end{array}$} \\
\hline & & & Spring & Winter & & Mass (kg) & No. & & Fruit & kg Fruit & \\
\hline Spiringen/Locherbach & Uri & Alps north & 4.1 & -3.4 & 7 Oct 08 & 0.877 & 27 & No & 0.00 & 0.00 & \\
\hline Riddes & Valais & Valais & 9.7 & 1.9 & 9 Sep 08 & 1.552 & 59 & Yes & 3.71 & 141.11 & 7.63 \\
\hline Le Guercet/Martigny & Valais & Valais & 9.6 & 1.7 & 9 Sep 08 & 3.868 & 69 & Yes & 5.42 & 96.69 & 9.48 \\
\hline Chateauneuf & Valais & Valais & 9.4 & 0.6 & 9 Sep 08 & 2.288 & 57 & Yes & 1.51 & 37.59 & 8.42 \\
\hline Sion & Valais & Valais & 9.4 & 0.2 & 9 Sep 08 & 3.888 & 84 & Yes & 2.46 & 53.24 & 6.56 \\
\hline Aigle & Vaud & Valais & 8.7 & 1 & 9 Sep 08 & 0.646 & 25 & Yes & 0.80 & 30.96 & 9.03 \\
\hline Rolle & Valais & Valais & 8.6 & 1.8 & 30 Sep 08 & 3.886 & 89 & Yes & 0.13 & 3.09 & \\
\hline Gampel & Valais & Valais & 8.4 & 0.1 & 8 Oct 08 & 1.720 & 53 & Yes & 0.28 & 8.72 & 7.16 \\
\hline Glis (dir. Eyholz) & Valais & Valais & 8.1 & -0.3 & 8 Oct 08 & 0.874 & 38 & Yes & 0.87 & 37.76 & 7.32 \\
\hline Montreaux & Vaud & Midlands & 9.4 & 2.4 & 9 Sep 08 & 1.402 & 44 & Yes & 3.16 & 99.14 & 10.53 \\
\hline Geneva & Geneva & Midlands & 9.3 & 2 & 9 Sep 08 & 1.753 & 62 & Yes & 1.45 & 51.34 & 8.19 \\
\hline Nyon & Vaud & Midlands & 8.8 & 1.5 & 30 Sep 08 & 0.744 & 33 & No & 0.00 & 0.00 & \\
\hline Etzgen & Aargau & Midlands & 8.8 & 1.2 & 17 Sep 08 & 1.053 & 22 & Yes & 7.27 & 151.95 & 7.62 \\
\hline Zürich-Zollikon & Zurich & Midlands & 8.7 & 0.9 & 2 Oct 08 & 8.667 & 255 & Yes & 5.76 & 169.61 & 9.20 \\
\hline Kaiserstuhl & Aargau & Midlands & 8.7 & 0.4 & 17 Sep 08 & 1.481 & 33 & No & 0.00 & 0.00 & \\
\hline Rietheim & Aargau & Midlands & 8.7 & 0.4 & 17 Sep 08 & 1.083 & 31 & Yes & 0.42 & 12.00 & 7.44 \\
\hline Leibstadt & Aargau & Midlands & 8.6 & 0.7 & 17 Sep 08 & 1.457 & 40 & Yes & 0.08 & 2.06 & 7.00 \\
\hline Schupfart & Aargau & Midlands & 8.5 & 1.2 & 17 Sep 08 & 1.092 & 37 & Yes & 2.16 & 73.26 & 10.53 \\
\hline Hottwil & Aargau & Midlands & 8.5 & 0.7 & 17 Sep 08 & 1.269 & 41 & No & 0.00 & 0.00 & \\
\hline Wädenswil & Zurich & Midlands & 8.5 & 0.7 & 22 Sep 08 & 1.937 & 47 & Yes & 0.45 & 10.84 & 7.53 \\
\hline Glattfelden & Zurich & Midlands & 8.5 & 0.3 & 17 Sep 08 & 0.644 & 30 & No & 0.00 & 0.00 & \\
\hline Wegenstetten & Aargau & Midlands & 8.2 & 1 & 17 Sep 08 & 0.875 & 30 & Yes & 0.40 & 13.71 & 7.27 \\
\hline Egnach/Romanshorn & Thurgau & Midlands & 8.2 & 0.6 & 24 Sep 08 & 1.160 & 26 & Yes & 0.00 & 6.90 & 7.03 \\
\hline Breitenhof & Basel-Land & Midlands & 8.1 & 0.6 & 17 Sep 08 & 1.950 & 47 & Yes & 4.21 & 101.54 & 7.32 \\
\hline Elfingen & Aargau & Midlands & 8.1 & 0.3 & 17 Sep 08 & 0.951 & 26 & Yes & 1.23 & 33.65 & 6.97 \\
\hline Pfungen & Zurich & Midlands & 8 & 0.2 & 17 Sep 08 & 1.237 & 37 & Yes & 2.05 & 61.44 & 8.95 \\
\hline Rorschacherberg & St. Gallen & Midlands & 7.9 & 0.7 & 24 Sep 08 & 1.083 & 26 & Yes & 0.58 & 13.85 & 8.73 \\
\hline Bern-Ostring & Bern & Midlands & 7.7 & 0 & 23 Sep 08 & 1.905 & 50 & Yes & 9.88 & 259.32 & 8.80 \\
\hline Langrickenbach & Thurgau & Midlands & 7.5 & -0.1 & 24 Sep 08 & 2.098 & 52 & No & 0.00 & 0.00 & \\
\hline Hirzel & Zurich & Midlands & 6.9 & -0.5 & 9 Oct 08 & 0.968 & 48 & No & 0.00 & 0.00 & \\
\hline St. Gallen & St. Gallen & Midlands & 6.5 & -0.7 & 24 Sep 08 & 1.419 & 35 & No & 0.00 & 0.00 & \\
\hline Lichtensteig & St. Gallen & Midlands & 6.2 & -1.1 & 24 Sep 08 & 1.201 & 39 & No & 0.00 & 0.00 & \\
\hline Auvernier & Neuchatel & Jura & 8.7 & 1.6 & 10 Sep 08 & 0.667 & 75 & Yes & 0.81 & 91.45 & 7.88 \\
\hline Courrendin & Jura & Jura & 8 & 0.4 & 10 Sep 08 & 1.134 & 28 & Yes & 7.71 & 190.48 & 7.76 \\
\hline Dombresson & Neuchatel & Jura & 6.7 & 0.1 & 10 Sep 08 & 1.895 & 47 & Yes & 3.81 & 94.46 & 9.00 \\
\hline St. Imer & Bern & Jura & 5 & 0.4 & 10 Sep 08 & 0.477 & 10 & No & 0.00 & 0.00 & \\
\hline
\end{tabular}

${ }^{1}$ Sampling impossible but no obvious infestation.

2 no nut trees albeit sufficient growing conditions. 
Appendix 2. Infestation patterns of Rhagoletis completa in the single-fruit experiment (five fruits per locality) listed in the same order as in table 1.

\begin{tabular}{|c|c|c|c|c|c|c|c|c|c|}
\hline \multirow[t]{2}{*}{ Locality } & \multirow[t]{2}{*}{ Climate } & \multicolumn{2}{|c|}{ Temperature $\left({ }^{\circ} \mathrm{C}\right)$} & \multicolumn{2}{|c|}{ Fruit weight (g) } & \multicolumn{2}{|c|}{$\begin{array}{l}\text { Pupae per fruit } \\
(n)\end{array}$} & \multicolumn{2}{|c|}{$\begin{array}{l}\text { Pupal weight } \\
\text { (mg) }\end{array}$} \\
\hline & & Spring & Winter & Mean & SE & Mean & SE & Mean & SE \\
\hline Bellinzona Carasso & Alps south & 10.9 & 2.7 & 40.30 & 1.75 & 10.40 & 2.77 & 6.63 & 1.76 \\
\hline Contone & Alps south & 10.8 & 2 & 42.64 & 2.45 & 2.00 & 1.26 & 4.30 & \\
\hline Vezia/Lugano & Alps south & 10.7 & 2.8 & 38.37 & 2.42 & 3.80 & 1.62 & 8.15 & 0.78 \\
\hline Castel San Pietro & Alps south & 9.4 & 0.6 & 43.34 & 4.76 & 13.20 & 5.83 & 7.22 & 0.87 \\
\hline Faido & Alps south & 8.3 & 0.6 & 39.01 & 2.93 & 18.20 & 3.54 & 7.10 & \\
\hline Brusio & Alps south & 7.9 & 0.5 & 33.31 & 0.91 & 10.00 & 1.00 & 7.89 & 0.97 \\
\hline Soglio & Alps south & 7.8 & -4.5 & 35.56 & 0.95 & 0.00 & & & \\
\hline Zizers & Alps north & 8.5 & 0.3 & 47.79 & 1.16 & 19.60 & 5.23 & 9.33 & 0.68 \\
\hline Chur & Alps north & 8.4 & 0.1 & 48.08 & 2.23 & 9.00 & 2.66 & 8.97 & 0.21 \\
\hline Riddes & Valais & 9.7 & 1.9 & 33.96 & 2.92 & 2.00 & 1.30 & 8.80 & \\
\hline Rolle & Valais & 8.6 & 1.8 & 34.67 & 2.43 & 0.00 & & & \\
\hline Gampel & Valais & 8.4 & 0.1 & 41.62 & 1.92 & 1.60 & 0.68 & 5.66 & 0.76 \\
\hline Glis (dir. Eyholz) & Valais & 8.1 & -0.3 & 26.10 & 1.15 & 0.40 & 0.24 & 8.30 & \\
\hline Montreaux & Midlands & 9.4 & 2.4 & 35.43 & 1.01 & 7.80 & 0.97 & 8.83 & 1.16 \\
\hline Geneva & Midlands & 9.3 & 2 & 36.33 & 3.99 & 9.80 & 2.89 & 8.24 & 1.31 \\
\hline Etzgen & Midlands & 8.8 & 1.2 & 42.91 & 2.84 & 14.60 & 2.44 & 6.88 & 0.74 \\
\hline Zürich-Zollikon & Midlands & 8.7 & 0.9 & 49.06 & 1.30 & 18.00 & 2.55 & 6.66 & 0.35 \\
\hline Schupfart & Midlands & 8.5 & 1.2 & 32.64 & 3.32 & 6.20 & 2.92 & 8.75 & 0.89 \\
\hline Wädenswil & Midlands & 8.5 & 0.7 & 47.57 & 2.49 & 4.80 & 2.33 & 10.74 & 0.23 \\
\hline Breitenhof & Midlands & 8.1 & 0.6 & 42.39 & 3.86 & 3.20 & 2.52 & 6.72 & 0.98 \\
\hline Pfungen & Midlands & 8 & 0.2 & 37.81 & 1.90 & 12.20 & 2.75 & 8.81 & 0.86 \\
\hline Bern-Ostring & Midlands & 7.7 & 0 & 38.49 & 2.33 & 14.20 & 4.49 & 6.52 & 0.77 \\
\hline Auvernier & Jura & 8.7 & 1.6 & 35.37 & 2.25 & 9.00 & 2.17 & 8.44 & 0.86 \\
\hline
\end{tabular}

